\title{
The value of benchmarks in thoracic surgery
}

\author{
Alan D. L. Sihoe ${ }^{1,2}$ \\ ${ }^{1}$ Gleneagles Hong Kong Hospital, Hong Kong, China; ${ }^{2}$ International Medical Centre, Hong Kong, China \\ Correspondence to: Alan D. L. Sihoe. 27th floor, International Medical Centre, 22 Des Voeux Road Central, Hong Kong, China. Email: asihoe@gmail.com. \\ Comment on: Wang Y, Luo J, Yang Y, et al. 2018 annual report of thoracic surgery service at Shanghai Chest Hospital. Shanghai Chest 2019;3:70.
}

Received: 08 January 2020. Accepted: 03 February 2020; Published: 10 October 2020.

doi: 10.21037/shc.2020.02.06

View this article at: http://dx.doi.org/10.21037/shc.2020.02.06

In a recent article, Wang and colleagues reported data on the surgical volume, procedures, and peri-operative outcomes of all the thoracic surgeries performed in 2018 by the Department of Thoracic Surgery and the Department of Thoracic Oncological of the Shanghai Chest Hospital (1). Of the 14,054 major thoracic operations performed in one year alone, $88.4 \%$ were performed using minimally invasive approaches and the 30-day mortality rate was a remarkable $0.21 \%$. The results are outstanding. However, the cynic would be entitled to ask: "so what?" Those with a proclivity towards envy would even dismiss annual reports such as this of being boasting or advertising for the authors' hospital. However, this would be small-minded thinking. By honestly and openly sharing their results with all readers, the authors are actually making a valuable contribution to patient care around the world.

It is well recognized that a higher volume of surgeries performed at an institute tend to correlate with better clinical outcomes and quality of care for patients $(2,3)$. Consequently, it is reasonable that the largest centers should set the standard for surgery, showcasing the best safety, survival and satisfaction that can be achieved for patients. Today, in thoracic surgery, the largest volume centers of all are found in China (4). The vast population in the country, coupled with great freedom to seek their preferred healthcare nationwide, means that ultra-high volume centers (UHVCs) have emerged in the biggest cities, dealing with huge numbers of operations. The Shanghai Chest Hospital ranks amongst the greatest of these UHVCs, as the numbers in their annual report attest (1). These figures may be referenced as the standard of care today, as those figures from the traditional 'large' centers in the rest of the world have for many years.

The importance of such data is that they report the benchmark. Benchmarking is defined as the comparative assessment of high-level performance (5). For medical professionals, benchmarking allows for identification of shortcomings and hence areas for improvement in one's own practice. The 'best possible' performance standard for a given field (say, thoracic surgery) is set as the benchmark. The relevant data from one's own practice is then compared with the benchmark, and the gaps identified. This then allows for considerations of the causes of and the solutions to narrow the gaps, resulting in service improvement.

Of course, proper benchmarking should go beyond simple comparison of crude data between centers or surgeons. A systematic methodology involving stratification of patients for comparison, specific definition of outcome measures, and careful calculation of compared values are essential $(5,6)$. However, the cornerstone of the process is to first have as a reference point the 'best possible' performance.

Viewed in this light, the annual report from the Shanghai Chest Hospital represents a generous sharing of data. Coming from one of the major UHVCs today, these results offer a potential 'best possible' reference point for benchmarking in thoracic surgery. It is up to the reader to digest the report objectively, and consider how the findings can best be used in auditing one's own performance. The best surgeons are invariably those that can learn from others.

\section{Acknowledgments}

Funding: None.

\section{Footnote}

Provenance and Peer Review: This article was commissioned by the editorial office, Shanghai Chest. This article did not undergo external peer review. 
Conflicts of Interest: The author has completed the ICMJE uniform disclosure form (available at http://dx.doi. org/10.21037/shc.2020.02.06). Dr. Sihoe reports nonfinancial support from Medela, other from Medtronic, other from Johnson \& Johnson.

Ethical Statement: The author is accountable for all aspects of the work in ensuring that questions related to the accuracy or integrity of any part of the work are appropriately investigated and resolved.

Open Access Statement: This is an Open Access article distributed in accordance with the Creative Commons Attribution-NonCommercial-NoDerivs 4.0 International License (CC BY-NC-ND 4.0), which permits the noncommercial replication and distribution of the article with the strict proviso that no changes or edits are made and the original work is properly cited (including links to both the formal publication through the relevant DOI and the license). See: https://creativecommons.org/licenses/by-nc-nd/4.0/.

doi: 10.21037/shc.2020.02.06

Cite this article as: Sihoe ADL. The value of benchmarks in thoracic surgery. Shanghai Chest 2020;4:35.

\section{References}

1. Wang Y, Luo J, Yang Y, et al. 2018 annual report of thoracic surgery service at Shanghai Chest Hospital. Shanghai Chest 2019;3:70.

2. Bach PB, Cramer LD, Schrag D, et al. The influence of hospital volume on survival after resection for lung cancer. N Engl J Med 2001;345:181-8.

3. Lüchtenborg M, Riaz SP, Coupland VH, et al. High procedure volume is strongly associated with improved survival after lung cancer surgery. J Clin Oncol 2013;31:3141-6.

4. Sihoe ADL, Han B, Yang TY, et al. The Advent of Ultrahigh Volume Thoracic Surgical Centers in Shanghai. World J Surg 2017;41:2758-68.

5. Staiger RD, Schwandt H, Puhan MA, et al. Improving surgical outcomes through benchmarking. Br J Surg 2019;106:59-64.

6. Staiger RD, Gutschow CA. Benchmark analyses in minimally invasive esophagectomy-impact on surgical quality improvement. J Thorac Dis 2019;11:S771-6. 